\title{
Where's the Party? Explaining Positions on LGBTQ Rights in Europe among Would-be MPs
}

\author{
Scott N. Siegel*, Stuart J. Turnbull-Dugarte ${ }_{+}$, and Brian Olinger
}

\section{Paper prepared for 2020 Virtual APSA Conference \\ September 2020}

\begin{abstract}
An extensive literature has formed that shows and explains why public opinion about LGBTQ rights has changed to dramatically and quickly. One of the effects has been the passage of numerous pieces of legislation that grant sexual minorities equal treatment. To advance the legal protection and egalitarian treatment afforded to LGBTQ citizens, activists need allies in parliament. This paper investigates what affects the views of parliamentary candidates on gay rights, independent of public opinion. Because in most parliamentary systems parties select their candidates, we would expect political ideology to play a strong role in shaping their views. However, drawing on rarely used data on the views and background of thousands of individual parliamentary candidates from countries across Europe and their policy preferences on the issue of same-sex marriage, our results show that political ideology and partisanship do not tell the whole story. Empirically, we demonstrate that parliamentary candidates' positions on same-sex marriage are determined more by their religious beliefs and other socio-demographic characteristics than by political ideology, even within parties traditional supportive of progressive social values. This study contributes to better understanding how LGBTQ policy change happens in Europe by examining the preferences of the people mainly responsible for it.
\end{abstract}

Keywords: Same-sex marriage, political parties, party candidates, LGBTQ politics, Europe

\footnotetext{
* Associate Professor, San Francisco State University

Corresponding author: snsiegel@sfsu.edu

† Assistant Professor, University of Southampton

$¥$ Research Assistant, San Francisco State University
} 


\section{Introduction}

Over the last two decades a number of Western democracies have engaged in a significant and rapid expansion of policy reforms aimed at remedying the institutional forms of discrimination against lesbian, gay, bisexual (LBG) individuals and other sexual minorities like transgender and queer citizens (TQ). One of the fundamental policy innovations that has taken places includes the legalization of same-sex marriage (SSM) which, following the entrepreneurial advocacy observed in the Netherlands (Kollman 2017), is now legalized in some sixteen European states and nine have some type of recognition of same-sex partnership (SSP) laws.1 State recognition of LGBTQ rights is important for the health and wellbeing of these communities. Not only does the provision of public policies that aim to provide equal recognition of same-sex couples have a positive and direct impact on improving the welfare of the LGBTQ community (Boertien and Vignoli 2019; Donnelly, Robinson, and Umberson 2019; Thomeer et al. 2018), it has also indirect effects. Abou-Chadi and Finnigan (2018), for example, show that the legalization of SSM exhibits a significant positive effect on public attitudes towards sexual minorities (Abou-Chadi and Finnigan 2018). In other words, when state legislatures move to provide institutional recognition of SSM, homo-negative feelings in the wider public are reduced which, we can assume, may reduce the propensity of LGBTQ individuals to experience intolerance and negative social experiences based on their sexuality or gender identity in their everyday lives.

Understanding what drives tolerant attitudes towards sexual minorities, including homosexuals and transgender individuals as well as citizen preferences towards concrete LGBTQ policy proposals like SSM and adoption rights for SS couples, has experienced a notable expansion within the literature. In this paper, we move beyond a

1 Data drawn from ILGA-Europe, "Rainbow Map 2020," https://rainbow-europe.org/\#0/8682/0 accessed August 22, 2020 . 
focus on support for LGBTQ rights within the public realm and focus on the preferences for equal treatment LGBTQ minorities (represented by support for a ban on SSM) amongst political party candidates. Considering the importance of elected representatives' role in determining the outcome of these policy decisions, particularly in Europe where strong and cohesive political parties are a central component of the European party government model (Schattschneider 1942), it is surprising we know very little about the determinants of individual aspiring representatives' support for LGBTQ rights issues. We fill the gap in our knowledge by presenting the first audit of political candidates' attitudes towards SSM, a core issue of equal treatment for the LGBTQ community.

Taking the issue of SSM as a prominent and contemporary LGBTQ rights concern in European states, we ask: what determines would-be MPs' attitudes towards SSM? We argue that understanding the individual sociological and political determinants of preferences towards SSM amongst the political class is important as it sheds light on how legislators come to form their preferences on salient political issues with real-world consequences for sexual minorities. Exploring what factors determine what drives aspiring MPs' attitudes towards SSM also helps us understand the extent to which the drivers of public support for SSM are mirrored across those that seek to present citizens in public office.

Empirically, we utilize individual-level data from over 27,000 political candidates across twenty-one European states to assess their level of support for a ban on SSM. Analyzing the socioeconomic attributes, political preferences and partisan association of candidates, we find a substantive and significant role of religion in shaping candidates' preferences above and beyond partisanship. In line with the assessments of "morality" politics within the policy-making process, which maintain that the "color of 
government is not a central factor" (Engeli, Green-Pedersen, and Larsen 2013) in determining policy outcomes, we show that partisan affiliation exhibits a large explanatory effect on candidates' preferences on SSM, but the relative effect of party membership is conditioned by a person's religiosity and their region of origin, even among post-materialist parties that are traditionally described as advocates for progressive cultural values.

The next section surveys the extant literature on the relationship between political parties and the advancement of LGBTQ rights in Europe to highlight the factors expected to affect political candidates' support for an SSM ban. Subsequently, we present descriptive statistical results of the candidates' positions and explain our research design. We then present the findings of our main regression analysis before providing a discussion of our conclusions and their implications.

\section{Why Party Candidates?}

A substantial body of evidence shows that public opinion on LGBT rights has changed dramatically since just twenty or thirty years ago across the developed and developing world. Not only has tolerance of homosexuality risen dramatically in the past thirty years in developed (Abou-Chadi and Finnigan 2018; Ayoub 2016; Garretson 2018; Kollman 2013) and developing countries alike (Ayoub and Garretson 2017), but also a substantial amount of legislation and judicial decisions have expanded the institutional equal treatment for some members of the LGBTQ community in law. The literature focuses prominently on one issue of equal treatment-same-sex marriage or partnership (SSM/SSP) laws, although anti-discrimination measures in the area of employment, joint adoption or equal access to IVF treatments, or nonsurgical requirements for changing one's gender on legal documents also receive attention. 
However, the passage of legislation improving the human rights situation for sexual minorities does not move in lock step with rising public opinion. Some governments move faster than predicted by the state of public opinion, while others lag behind. For example, Spain adopted SSM in 2005 , despite only $62 \%$ of the population supporting the measure.2 In contrast, Switzerland has still not approved SSM laws despite support currently standing at over 80\%.3 Conversely, Poland's current government, consisting of the rightwing, populist Law and Justice Party (PiS), is leading a backlash against LGBTQ minorities, despite generally more favorable attitudes of gays and lesbians nationally than they were during democratic transition. Poland could become an example of how countries have rolled back of pro-LGBTQ legislation or the adoption of constitutional bans on SSM, despite growing tolerance for homosexuality and support for SSM (Velasco 2020). Thus, who is in power and their ideological positions on LGBT rights clearly matters for whether there is progress or retrenchment, primarily because acts of parliament have been the core avenue via which LGBT equality has advanced, with the exception of Ireland, Austria (Turnbull-Dugarte 2020), in Europe.

In addition, there is clear evidence that support for SSM marriage varies across European political parties (Hildebrandt 2016), suggesting which parties are in government and their positions on LGBT rights matters. Early research shows that where Greens and social democratic parties have tended to be the core advocates of expanding LGBTQ legislation (B. D. Adam 2003; Calvo 2007; Díez 2015; Fernández and Lutter 2013; Schulenberg 2012). Yet, Hildebrandt (2016) and other found centrist and center-right parties have also favored and adopted SSM marriage laws. Siegel and

2 Agnus Reid Global Monitor, "Same-Sex Marriage Legislation OK in Spain," Angus Reid Global Monitor, July 2, 2005, https://web.archive.org/web/20071227092736/http://www.angus-reid.com/polls/view/7887 (accessed August 29, 2020).

3 Sibilla Bondolfi, "Survey Shows Broad Swiss Support for Same-Sex Marriage," Swissinfo.ch, February 10, 2020, https://www.swissinfo.ch/eng/lgbt_survey-shows-widespread-swiss-support-for-same-sex-marriage/45549724 (accessed August 29, 2020). 
Wang (2018) show that these inconclusive findings are due to a reliance on classical measures of party ideology. Instead, if party ideology is measured exclusively on the post-materialist spectrum, those parties further to the left, which includes some parties traditionally found on the center-right, then SSM laws are more likely to be adopted SSM/SSP laws are adopted, irrespective of where they lie on the left-right political dimension (Siegel and Wang 2018). Thus, even center-right parties in Protestant or mixed-confession countries have adopted pro-LGBT legislation.

Whilst political parties have been at the heart of the expansion of LGBTQ rights in European states, political parties are not a monolith, nor do they operate as a unitary actor. Parties tend to be made up of three constitute 'faces': the party on the ground (members); the party in central office (staffers and administrators) and the party in public office (elected representatives) (Katz and Mair 1993). Among these three components, those in public office have the greatest impact on government policy. They do not just represent their constituents' interests, but design and craft policy according to their own agenda. They are also the main gatekeepers for any policy change. Dramatic policy change, such as implementing SSM laws or permitting adoption by same-sex couples, is unlikely to happen unless it receives support from large shares those party members sitting in parliament. Individual party members can also, under certain conditions, play a key role in the decision-making process when it comes to designing party manifestos (Hennl and Franzmann 2017). After all, individual parliamentarians must present themselves for election, even in list systems where the party selects the candidates, and ultimately serve as the representative actors of the party's constituents, and that create and shape the legislative policies presented in the legislature. Party members preferences on morality issues do not always match those of their constituents. There is significant evidence that the preferences of legislators can be more extreme than those of their constituents, either more restrictive (Norrander and Wilcox 1999) or more permissive (McAllister 1991), 
In addition to helping us understand what the "party in public office" thinks in general, assessing MP-level preferences can also help us understand legislative voting behavior. Legislative voting on so called "morality politics" are a unique subset of policy areas where partisanship is far less likely to play a constraining and incentivizing role over legislators' preferences (Engeli, Green-Pedersen, and Larsen 2012). Policy concerns that have typically been tagged within the umbrella of morality concerns include, amongst others, embryo and stem-cell research (Arzheimer 2015, 2020; Banchoff 2011), reproductive rights, euthanasia (C. Adam, Knill, and Budde 2020; Engeli, Green-Pedersen, and Larsen 2013), and SSM rights (C. Adam, Knill, and Budde 2020; Chaqués and Roqué 2012).

Morality issues are distinct from "bread and butter" politics in that public and legislators' views on these issues are more likely to be informed by a core set of fundamental values unique to the individual which makes them less amenable to partisan cues and whips (Engeli, Green-Pedersen, and Larsen 2012; Mooney 2001). The evidence is mixed at best regarding whether individuals' beliefs and attitudes affect preferences over LGBTQ policies or party identity (Arzheimer 2015; Plumb 2015). When voting on these issues, representatives are typically released from the confines of enforced party discipline and permitted to vote in accordance with their own moral value system (Cowley 1998). In essence, these "free votes" reduce the partisan distinction of legislature voting behavior, allowing individuals representatives to decide how to vote based on their own moral compass (C. Adam, Knill, and Budde 2020). For example, when free votes were taken in Westminster parliamentary systems (UK, New Zealand and Australia), there was support across the political spectrum for SSM (Plumb 2015). In addition, when the SPD, junior partner in the third Merkel-led coalition government pushed SSM as a possible election issue in 2017, Chancellor Merkel pre- 
empted them by holding a vote of conscious in the Bundestag on SSM and approximately $25 \%$ of CDU parliamentarians voted in favor of SSM. Although the overall evidence is mixed, these examples show that the preferences of individual candidates for parliament matter as much as the ideological orientation of the incumbent government.

These arguments for examining party candidate's positions on SSM are all on the demand side. The supply-side also matters. Political candidates do not just react to changing public opinion among their constituents. Political elites are also key in shaping public opinion, especially when the issue is not salient among voters and involves complex morality issues (Mucciaroni, Ferraiolo, and Rubado 2019). They inform and persuade their constituents. They broadcast their views and help voters decide which issues to prioritize over others. Thus, the views of political candidates themselves are important for how and when public opinion can shift. In some cases, they can move national publics forward towards more LGBT equality, such as in the United States, or slightly backwards, such as in Poland. Finally, like in the United States, party membership is increasingly becoming a core part of an individual's social identity in Europe (Wagner 2020). As a result, attitudes over social issues are increasingly reflective of the party's positions rather than non-party sources, such as religion or level of education.

For these reasons, we argue that where candidates lie on the political spectrum on cultural values deserves exploration. Furthermore, we claim where the classic right/left political spectrum is not always helpful in predicting support for LGBT rights._The political space in Europe is no longer unidimensional and is made up of different and not necessarily correlated axes of conflict (Adams et al. 2004; Bakker, Jolly, and Polk 2012; Bornschier 2010; Caughey, O’Grady, and Warshaw 2019; Hooghe, Marks, and 
Wilson 2002; Kitschelt 1994). Research has found that the postmaterialist GAL/TAN (Green-Alternative-Libertarian/Traditionalist-Authoritarian-Nationalist), positions better explain when same-sex partnership or same-sex marriage legislation is approved by parties than the classic left-right 'super issue' (Siegel and Wang 2018). For that reason, we disaggregate the political space and candidate preferences across both the traditional left/right economic cleavage as well as socio-cultural cleavage. While our analysis is exploratory, we investigate the relative effect party ideology has on preferences over pro-LGBTQ equality legislation compared to socio-demographic factors and cultural attitudes already found to affect public attitudes towards LGBTQ rights.

H1: (party thesis): Left-leaning party candidates will be more prone to oppose an SSM ban.

\section{Alternative Explanations: Demographic characteristics and Cultural Values}

As Engeli et al. (2012) argue, attitudes towards homosexuality and gay rights have been formed long before parties took positions on the issues. Positions on morality issues, sometimes stemming from religion, are formed early on in an individual's formative years, involve high levels of socialization, and are difficult to change (Goren and Chapp 2017, 110). As a result, we can expect that individual-level demographic factors, such as, gender, family status, education, income and religion, retain a substantive explanatory role over and above party identity with regards to candidates' position on SSM laws. People who are married with children tend to be less tolerant than those who are single or divorced (Dejowski 1992) and people who live in communities where marriage rates are higher are less tolerant (McVeigh and Diaz 2009). People with higher levels of education have consistently shown to be at higher levels of tolerance towards sexual minorities, especially those who completed a university degree 
(Stubager 2009, 2013). Men tend to be less tolerant of homosexuality than women. In the US, for example, Twenge and Blake (2020) show that, conditioning on generational replacement across cohorts, women remain sizably more supportive of SSM than men (Twenge and Blake 2020). In Europe, Dotti-Sani and Quaranta (2020) rely on European Social Survey data from twenty-two different countries to analyze support for homosexuality (measured as agreement with the statement "Gays and lesbians should be free to live as they wish") and same-sex adoption rights. Older voters are have more conservative social values and, therefore, tend to be less tolerant of sexual and gender differences than younger ones (Dotti Sani and Quaranta 2020). Notably, in the case of the successful referendum on a constitutional prohibition to same-sex marriage in Croatia, Glaurdić and Vukovic (2016) observe a significant positive correlation between the those municipalities with an older voting population and increased support for the ban.

Cultural attitudes towards same-sex marriage are strongly determined by how intensely a person's religious beliefs are held. As countries develop economically, tribal and materialist values begin to lose their importance and instead people turn to values that recognize one's individual identity (Inglehart 1997). It is generally accepted that increased tolerance for homosexuality is positively correlated with economic advancement (Asal, Sommer, and Harwood 2013; Oppenheimer, Oliveira, and Blumenthal 2014; Štulhofer and Rimac 2009). While levels of economic development are helpful for comparing national patterns, they are less helpful for explaining individuals' attitudes, as religious individuals are found in wealthy and poor societies alike. We expect that individuals who attend religious services regularly continue to hold traditional values that make them less open to adopting same-sex marriage laws.

Finally, we need to consider the divergent socio-economic paths of development between countries from capitalist Europe and post-communist countries and how that 
is likely to affect political candidates' views on SSM laws. While post-communist countries, on average, are less wealthy and economically developed than Western, capitalist ones, low levels of development alone do not predict higher rates of homonegativity in them. Instead, lower levels of tolerance are attributed to the lingering effects of Soviet ideology that suggests homosexuality is associated with decadent Western values (Janos 2001), the more substantial role religion has in politics in postcommunist countries (Grzymala-Busse 2015), and how conservative religious values and national identity has been fused together in some post-communist countries to oppose Europeanization and the import of progressive norms (Ayoub 2014; O'Dwyer and Schwartz 2010). Thus, we expect that candidates from post-communist countries are more likely to support a SSM ban than their peers from the same party families in Western Europe.

H2: (socio-demographic thesis): The relationship between candidates' sociodemographics and opposition to an SSM ban will reflect the link between pubic demographics and attitudes towards SSM.

H3 (religiosity thesis): Candidates' religiosity will determine opposition to an SSM ban, even when conditioning on partisanship."

\section{Data Description and Analysis}

The Comparative Candidates Survey (CCS) provides a range of information concerning the policy positions, attitudes, and socio-demographic background of parliamentary candidates running for office (CCS 2016). The CCS is the only dataset we know of that uses approximately the same uniform questionnaire across multiple countries and time. Both challengers and incumbents are included across several countries and election cycles in two waves over a five-year time span between 2005 and 2013 and again between 2013 and 2018. This yields a sample of over 27,000 parliamentary candidates. Some countries are surveyed more than once, with some 
surveyed as often as three times across the entire period, while others were only surveyed once.4

Respondents (candidates) were matched to the ideological party families to which they belong to the party family typology applied by ParlGov (Döring and Manow 2019).5 The distribution of candidates along the ideological spectrum in the sample roughly matches the size of the parties in European countries. For instance, a majority of respondents came from the five largest European party families-Christian Democrats, Conservatives, Liberals, Greens and Social Democrats. Socio-demographic information about the candidates was also gathered, including income, age, level of education, gender, marital status, faith, and degree of religious observance. Summary statistics are located in Appendix Table A.

When estimating support for LGBT rights in the general public, public opinion surveys ask individuals about their general attitudes or level of support for gay rights that ask about specific support for same-sex marriage (SSM) or same-sex partnerships (SSP) (WVS/EVS), tolerance of homosexuality, or experience with discrimination (Eurobarometer, etc.). In contrast, the CCS measures support for LGBTQ rights is gauged by candidates' responses with regard to specific item of legislation: whether a ban on SSM should be adopted. Responses range from according to the extent they agree with this statement from strongly agree (1) to strongly disagree (5), which was asked in all survey waves, but not asked the same way in each country every year.6 The advantage of this question over those in public surveys is that it requires respondents

4 For more information on the details of the survey process, go to http://www.comparativecandidates.org.

5 This was done with the help of the PartyFacts datasets which assign a unique code to each party that enables matching political parties across different databases (https://partyfacts.herokuapp.com).

6 In both survey waves, candidates were asked to what extent they agree that "same-sex marriages should be prohibited by law." However, since same-sex marriage was legal in Belgium starting in 2003, Belgian candidates were asked the degree they agreed "the marriages of gay/lesbians should be furthermore recognized," and the responses reversed to match responses to the former question. Similarly, in 2006 in the Czechia Republic, candidates were asked the degree to which they agreed that "it is good that a registered partnership of homosexuals exists," and the responses reversed. 
to take a specific policy position on the issue of same-sex marriage rather than just express their general attitudes towards homosexuality or same-sex marriage. The question elicits what real actions a candidate might take on LGBTQ rights rather than just acting as a political thermometer. Thus, we are better able to gauge what a politician will do when actual legislation is being considered in parliament. In other words, we take our measure to a be a specific indicator of SSM support/opposition as opposed to a diffuse measure of the acceptance of homosexuality.

\section{Descriptive Results}

To analyze the determinants of support for an SSM ban among would-be MPs, we estimate a multivariate regression model. Before engaging in this regression analysis, however, we present important descriptive findings.

Table 1 shows the average percentage of candidates from each party family according to their relative level of support for a ban on same-sex marriage across the entire time period contained in the sample. As expected, parties belonging to the centerright Christian Democrats, followed closely by Conservatives and those in the Rightwing family were most supportive of a ban, while communist and ecological party family members are the most opposed. The second column shows the change in average views between the earliest to the latest year the question was asked.7 Among all party families, candidates' grow more opposed to an SSM ban and to "strongly oppose." Liberal parties change their views the most in terms of opposing an SSM ban with substantially more candidates from Liberal parties responding "strong disagree," while members of Christian Democratic families move in relatively equal proportions from opposition to ambivalence ("neither agree nor disagree") or to strong opposition. Although members of far-left and center-left parties are always opposed to the SSM in large members, the share of members with those views continues to increase over time.

7 It is important to note that some countries fall in and out of the sample over time, and some countries are surveyed multiple times, while others only once. 
Conversely, no party family sees an increase in support for an SSM ban suggesting candidates were somewhat following trends in the general public.

Table 1. Attitudes Across Party Families

\begin{tabular}{|c|c|c|c|c|c|c|c|c|c|c|}
\hline \multicolumn{11}{|c|}{$\begin{array}{l}\text { \% Support for Ban on Same-Sex Marriage \& Average Change } \\
\text { (Across Party Families from 2005-2017 in All Countries) }\end{array}$} \\
\hline & \multicolumn{2}{|c|}{ Strongly Agree } & \multicolumn{2}{|c|}{ Agree } & \multicolumn{2}{|c|}{ Neither } & \multicolumn{2}{|c|}{ Disagree } & \multicolumn{2}{|c|}{$\begin{array}{l}\text { Strongly } \\
\text { Disagree }\end{array}$} \\
\hline & Mean & $\Delta$ & Mean & $\Delta$ & Mean & $\Delta$ & Mean & $\Delta$ & Mean & $\Delta$ \\
\hline Agricultural & 13 & -2 & 7 & -1 & 9 & -2 & 14 & -4 & 47 & +9 \\
\hline Chr. Dem. & 35 & -4 & 18 & -.5 & 22 & +4 & 15 & -0.6 & 13 & +6 \\
\hline Communist & 4 & -.53 & 3.6 & -1 & 6.3 & -.15 & 17 & -1.9 & 66 & +1.1 \\
\hline Conservative & 27 & -12 & 16 & -4.0 & 12 & -2 & 16 & -5 & 29 & +14 \\
\hline Ecological & 11 & -2 & 4 & -1.5 & 5 & -2 & 12 & -1 & 67 & -2 \\
\hline Liberal & 8 & -3 & 10 & -5 & 13 & -5.3 & 13 & +.09 & 48 & +7.1 \\
\hline Rightwing & 26 & -15 & 14 & -13 & 19 & -4.4 & 10 & -5 & 28 & +26 \\
\hline Socialist & 10 & +0.07 & 8 & +0.17 & 9 & -3 & 17 & -5 & 53 & +5 \\
\hline Special & 7 & & 22 & & 16 & & 32 & & 67 & -20 \\
\hline Total (0/) & 120 & & 801 & & 903 & & 1475 & & 5441 & \\
\hline & & & & & & & & & & \\
\hline & & & & & & & & & & \\
\hline
\end{tabular}

Yet, the extent to which candidates change their positions varies by country within each party family. For example, Swiss Conservatives (BDP) candidates show the biggest swing in support over time, whereby over $40 \%$ move from strongly agree to strongly disagree with a ban in approximately eight years. Significant proportions of candidates from Conservative party candidates in Czechia and Liberals in Germany also switch from supporting to opposing an SSM ban. These shifts are smaller or negligible in most other post-communist countries. Consistent with earlier research (Kollman 2007), candidates for election in capitalist as well as Protestant countries are more opposed to the SSM ban than those in post-communist and some Catholic countries, with Austrian candidates most supportive of an SSM ban, and Estonia, Montenegro and Hungary with the highest support among post-communist countries. Yet, opposition to a ban on SSM rises among candidates in most countries over time. The largest shifts within a 
country are in Belgium (2007-2014), Portugal (2007-2015), and Switzerland (20072015). Table 2 lists the distribution of support for a ban on SSM across countries.

Table 2. Percent Support for Ban on Same-Sex Marriage* (Across Countries)

\begin{tabular}{|c|c|c|c|c|c|c|c|c|c|c|}
\hline & \multicolumn{2}{|c|}{ Strongly Agree } & \multicolumn{2}{|l|}{ Agree } & \multicolumn{2}{|c|}{ Neither } & \multicolumn{2}{|c|}{ Disagree } & \multicolumn{2}{|c|}{$\begin{array}{l}\text { Strongly } \\
\text { Disagree }\end{array}$} \\
\hline & $\begin{array}{l}\text { Latest } \\
\text { Year }\end{array}$ & $\Delta$ & $\begin{array}{c}\text { Latest } \\
\text { Year }\end{array}$ & $\Delta$ & $\begin{array}{l}\text { Latest } \\
\text { Year }\end{array}$ & $\Delta$ & $\begin{array}{c}\text { Latest } \\
\text { Year }\end{array}$ & $\Delta$ & $\begin{array}{c}\text { Latest } \\
\text { Year }\end{array}$ & $\Delta$ \\
\hline Belgium & $\begin{array}{c}2 \\
(2014)\end{array}$ & $\begin{array}{c}-42 \\
(2007) \\
\end{array}$ & 3 & -23 & 7 & -4 & 20 & +14 & 44 & +35 \\
\hline Czech Republic & $\begin{array}{c}14 \\
(2017)\end{array}$ & $\begin{array}{c}-15 \\
(2006) \\
\end{array}$ & 11 & -5 & 13 & -.36 & 14 & -4 & 36 & +18 \\
\hline Estonia & $\begin{array}{c}27 \\
(2015)\end{array}$ & $\begin{array}{c}-7 \\
(2011)\end{array}$ & 16 & -2 & 8 & -11 & 13 & -3 & 11 & +4 \\
\hline Finland & $\begin{array}{c}18 \\
(2015)\end{array}$ & $\begin{array}{c}.71 \\
(2011)\end{array}$ & 6 & -1 & 7 & -1 & 6 & -6 & 58 & +7 \\
\hline Germany & $\begin{array}{c}8 \\
(2017)\end{array}$ & $\begin{array}{c}+3.9 \\
(2009)\end{array}$ & 3 & -1 & 3 & -4 & 8 & -2 & 75 & +5 \\
\hline Greece & $\begin{array}{c}11 \\
(2015)\end{array}$ & $\begin{array}{c}+5 \\
(2007)\end{array}$ & 13 & +.82 & 18 & -13 & 28 & +7 & 23 & +14 \\
\hline Iceland & $\begin{array}{c}1 \\
(2017)\end{array}$ & $\begin{array}{c}-1 \\
(2009)\end{array}$ & 0.00 & 0 & 3 & -1 & 14 & 6 & 72 & +19 \\
\hline Montenegro & $\begin{array}{c}20 \\
(2016)\end{array}$ & $\begin{array}{c}-4 \\
(2012) \\
\end{array}$ & 13 & -1 & 16 & -.72 & 22 & -1 & 8 & -2 \\
\hline Norway & $\begin{array}{c}3 \\
(2013) \\
\end{array}$ & $\begin{array}{c}-6 \\
(2009) \\
\end{array}$ & 2 & -2 & 7 & -3 & 5 & -3 & 79 & +15 \\
\hline Portugal & $\begin{array}{c}2 \\
(2015) \\
\end{array}$ & $\begin{array}{c}-13 \\
(2007) \\
\end{array}$ & 3 & -11 & 9 & -6 & 18 & +8 & 64 & +22 \\
\hline Sweden & $\begin{array}{c}1 \\
(2014)\end{array}$ & $\begin{array}{c}-2 \\
(2010)\end{array}$ & 1 & -1 & 3 & -4 & 7 & -6 & 63 & +5 \\
\hline Switzerland & $\begin{array}{c}10 \\
(2015)\end{array}$ & $\begin{array}{c}-12 \\
(2007) \\
\end{array}$ & 5 & -5 & 7 & -.36 & 8 & -4 & 63 & +18 \\
\hline \multicolumn{11}{|l|}{ Others } \\
\hline Austria & $\begin{array}{c}36 \\
(2008)\end{array}$ & & 20 & & 9 & & 11 & & 19 & \\
\hline Denmark & $\begin{array}{c}4 \\
(2011)\end{array}$ & & 2 & & 8 & & 4 & & 57 & \\
\hline Great Britain & $\begin{array}{c}11 \\
(2010)\end{array}$ & & 8 & & 13 & & 20 & & 42 & \\
\hline Hungary & $\begin{array}{c}29 \\
(2014)\end{array}$ & & 9 & & 7 & & 15 & & 18 & \\
\hline Ireland & $\begin{array}{c}11 \\
(2007)\end{array}$ & & 19 & & 17 & & 28 & & 22 & \\
\hline Italy & $\begin{array}{c}10 \\
(2013)\end{array}$ & & 12 & & 16 & & 23 & & 37 & \\
\hline Malta & $\begin{array}{c}14 \\
(2013) \\
\end{array}$ & & 19 & & 9 & & 23 & & 30 & \\
\hline Netherlands & $\begin{array}{c}11 \\
(2006)\end{array}$ & & 4 & & 4 & & 21 & & 57 & \\
\hline Rumania & $\begin{array}{c}24 \\
(2016)\end{array}$ & & 15 & & 35 & & 9 & & 13 & \\
\hline
\end{tabular}


We observe small upticks in the support of an SSM ban in only two countries (Greece and Germany), which is largely due to the inclusion of rightwing populists that had emerged and their strong opposition to SSM laws.

In summary, a review of candidates' positions on the SSM ban shows that the gap between rightist and leftist parties on the issue of SSM narrowed considerably, with the exception of candidates from the rightwing populist parties. However, a gap between candidates from capitalist and post-communist countries continues, relatively irrespective of to which party family candidate belongs. Still, there appears a secular trend over time towards greater acceptance of same-sex marriage that parallels changes in mass public opinion irrespective of where the party is situated on the political spectrum.

\section{Regression Analysis}

We now assess what factors best predict a parliamentary candidate's position on an SSM ban. We test indicators of a candidate's political ideology against a battery of sociodemographic factors. We use a hierarchical multivariate logistic model to estimate the independent effect of different socio-demographic and political determinants on attitudes towards the prohibition of same-sex marriage.

First, we transform the response variable from ordinal to one that is dichotomous: indicating if a respondent either disagreed or strongly disagreed with an SSM ban (1), or otherwise (0). Doing so not only simplifies the analysis, but better conceptualizes whether a candidate supports equal treatment for LGB individuals. The response "neither agree nor disagree" is coded as supportive of an SSM ban as indifference by individuals is not likely to produce active opposition to discriminatory legislation. 
Second, we measure partisanship in several ways. First, we a rate a candidate's party ideology according to the party to which they stood for in election along two separate ideological dimensions - the general Left-Right (labour-capital) dimension and where they are positioned on the post-materialist (GAL-TAN) spectrum. To detect individual party effects, we assigned a categorical variable to each European party family to which a candidate's party belongs according to their classification by Döring and Manow (2019).8 Social democratic parties are adopted as the reference category for two reasons. First, they make up one of the largest party families in Europe. Secondly, social democratic parties have tended to be the primary proponents of advancement in LGBTQ welfare (Hildebrandt 2016, 411) and, therefore, where we expect to see the highest level of opposition to an SSM ban.

We test the role of political ideology and party ID compared to other sociodemographic factors that individuals' attitudes towards equal treatment for sexual minorities - gender, marriage status, age, level of education and frequency of religious attendance. A dummy variable is introduced to control for a person's country of origin as a capitalist (1) or post-communist regime (0). To detect temporal variation, we control for the year in which the candidate was surveyed. Given observations represent party candidates within different European countries, we estimate a multilevel logistic regression model with countries as the level- 2 unit of analysis, in order to cater for potential between-state variation.

Results

8 Döring and Manow (ParlGov) classify parties according to the position on the economic and cultural political dimensions. This yields 8 party families: Communist/Socialist, Green/Ecologist, Social Democracy, Liberal, Christian Democracy, Agrarian, Conservative, and Rightwing. Their classification is constant over time, despite changing ideologies and constituencies, such as the Swiss People's Party, which started as an agrarian party now arguable belongs to the rightwing populist party family (Norris and Inglehart 2019) 
Table 3 reports the output of two different logistic regression models estimating support for an SSM ban amongst would-be MPs. The first model estimates the average effects of basic socioeconomic determinants of opposition to a ban. Model 2 includes the addition of our partisanship variable and indicators of ideology.

Table 3: Logistic regression models on opposition to an SSM ban

\begin{tabular}{|c|c|c|}
\hline $\mathrm{X}$ & $\begin{array}{c}(1) \\
\text { Oppose SSM Ban }\end{array}$ & $\begin{array}{c}(2) \\
\text { Oppose SSM ban }\end{array}$ \\
\hline Gender & $\begin{array}{c}-0.47 * * * \\
(0.04)\end{array}$ & $\begin{array}{c}-0.38 * * * \\
(0.04)\end{array}$ \\
\hline \multicolumn{3}{|l|}{ Age (ref: $18-45$ years) } \\
\hline $46-55$ years & $\begin{array}{c}0.33 * * * \\
(0.07)\end{array}$ & $\begin{array}{c}0.29 * * * \\
(0.08)\end{array}$ \\
\hline $56+$ & $\begin{array}{c}0.60 * * * \\
(0.07)\end{array}$ & $\begin{array}{c}0.51 * * * \\
(0.08)\end{array}$ \\
\hline \multicolumn{3}{|l|}{ Education (ref: Primary) } \\
\hline Secondary & $\begin{array}{l}0.33 * * \\
(0.13)\end{array}$ & $\begin{array}{c}0.41 * * * \\
(0.15)\end{array}$ \\
\hline Post-secondary & $\begin{array}{c}0.74 * * * \\
(0.12)\end{array}$ & $\begin{array}{c}0.77 * * * \\
(0.14)\end{array}$ \\
\hline Married & $\begin{array}{c}-0.31 * * * \\
(0.04)\end{array}$ & $\begin{array}{c}-0.10^{* *} \\
(0.05)\end{array}$ \\
\hline \multicolumn{3}{|l|}{ Party Family (ref: Social Democrat) } \\
\hline Agrarian & & $\begin{array}{c}0.10 \\
(0.14)\end{array}$ \\
\hline Christian Democrat & & $\begin{array}{l}-0.14 \\
(0.12)\end{array}$ \\
\hline Communist & & $\begin{array}{c}-0.50 * * * \\
(0.11)\end{array}$ \\
\hline Conservative & & $\begin{array}{c}0.16 \\
(0.13)\end{array}$ \\
\hline Greens & & $\begin{array}{c}-0.83 * * * \\
(0.09)\end{array}$ \\
\hline Liberal & & $\begin{array}{c}0.03 \\
(0.11)\end{array}$ \\
\hline Right & & $\begin{array}{l}0.29 * * \\
(0.14)\end{array}$ \\
\hline Special issue & & $\begin{array}{l}1.17 \\
(0.72)\end{array}$ \\
\hline Ideology: Economic (Left-right) & & $\begin{array}{c}-0.14 * * * \\
(0.02)\end{array}$ \\
\hline
\end{tabular}




\begin{tabular}{|c|c|c|}
\hline Ideology: Cultural (GAL/TAN) & & $\begin{array}{c}-0.34 * * * \\
(0.02)\end{array}$ \\
\hline \multicolumn{3}{|l|}{ Religious attendance (ref: never) } \\
\hline Rarely/once a year & & $\begin{array}{c}-0.40 * * * \\
(0.06)\end{array}$ \\
\hline Few times a year & & $\begin{array}{c}-0.70 * * * \\
(0.06)\end{array}$ \\
\hline Numerous times a month & & $\begin{array}{c}-1.60 * * * \\
(0.08)\end{array}$ \\
\hline CEEC & $\begin{array}{c}-1.93 * * * \\
(0.49)\end{array}$ & $\begin{array}{c}-1.95 * * * \\
(0.55)\end{array}$ \\
\hline Year & $\begin{array}{c}0.14 * * * \\
(0.01)\end{array}$ & $\begin{array}{c}0.16^{* * * *} \\
(0.01)\end{array}$ \\
\hline Constant (Country) & $\begin{array}{c}0.75 * * * \\
(0.25)\end{array}$ & $\begin{array}{c}0.94 * * * \\
(0.31)\end{array}$ \\
\hline Constant & $\begin{array}{c}-276.66^{* * *} \\
(14.04)\end{array}$ & $\begin{array}{c}-319.15^{* * *} * \\
(16.33)\end{array}$ \\
\hline Observations & 19,872 & 19,618 \\
\hline Number of groups & 19 & 19 \\
\hline
\end{tabular}

The results from Model 1, are largely in line with our expectations. Looking at the socio-demographic variables, we find results that both coincide with and challenge evidence based on what drives attitudes towards homosexuality amongst the public. In line with expectations, we find that male candidates are significantly less likely to oppose an SSM ban, echoing the established gender gap between men and women with regard to LGBTQ issues. The effect of age, however, is less intuitive: older candidates are, on average, significantly more likely to oppose an SSM ban in comparison to their younger colleagues aspiring to political office.

In terms of education, we observe a significant increase in opposition to the prohibition of SSM associated with increased educational attainment: those with a postsecondary education are significantly more supportive of SSM than those with lower levels of education. In terms of marital status, we find that married candidates are significantly less opposed to bans on SSM. 
Model 2 includes the addition of our party and ideology variables. For an interpretable understanding of the effect sizes from our multilevel logistic model, we focus on interpreting the average marginal effects (Figure 1). Our results show that, controlling for individual-level socio-economic determinants, partisan associations still matter, although the effects are not significant amongst mainstream parties. We find, for example, no significant difference between the probability of opposing an SSM ban between Social Democratic candidates (reference category) and Christian Democratic candidates or the candidates of Liberal parties. Where we do observe a significant gap between partisan candidates, is between Social Democratic and Green party or Communist party candidates. The former are 12 percentage-points less likely to oppose the prohibition of SSM whereas the effect is close to 7 percentage-points in the case of the communists.

Turning towards ideological determinants, we find that candidates on the right are significantly less likely to oppose an SSM ban as are those who are closer to the authoritarian pole of the GAL-TAN axis. The magnitude of the effect is notably greater in the case of the latter. Looking at the average marginal effects from Model 2 reported in Figure 1 shows that a one-unit step rightwards of the left-right axis is associated with a 2 percentage-point decrease in the probability of opposing a ban, whilst a one-unit increase in authoritarianism causes a 4.9 percentage-point reduction in the same. This provides further support that the cultural dimension of politics is a more efficient and accurate indicator of what drives politicians to support LGBT rights, in contrast to aggregate measures of ideology as part of the classic unidimensional left/right "super space". 


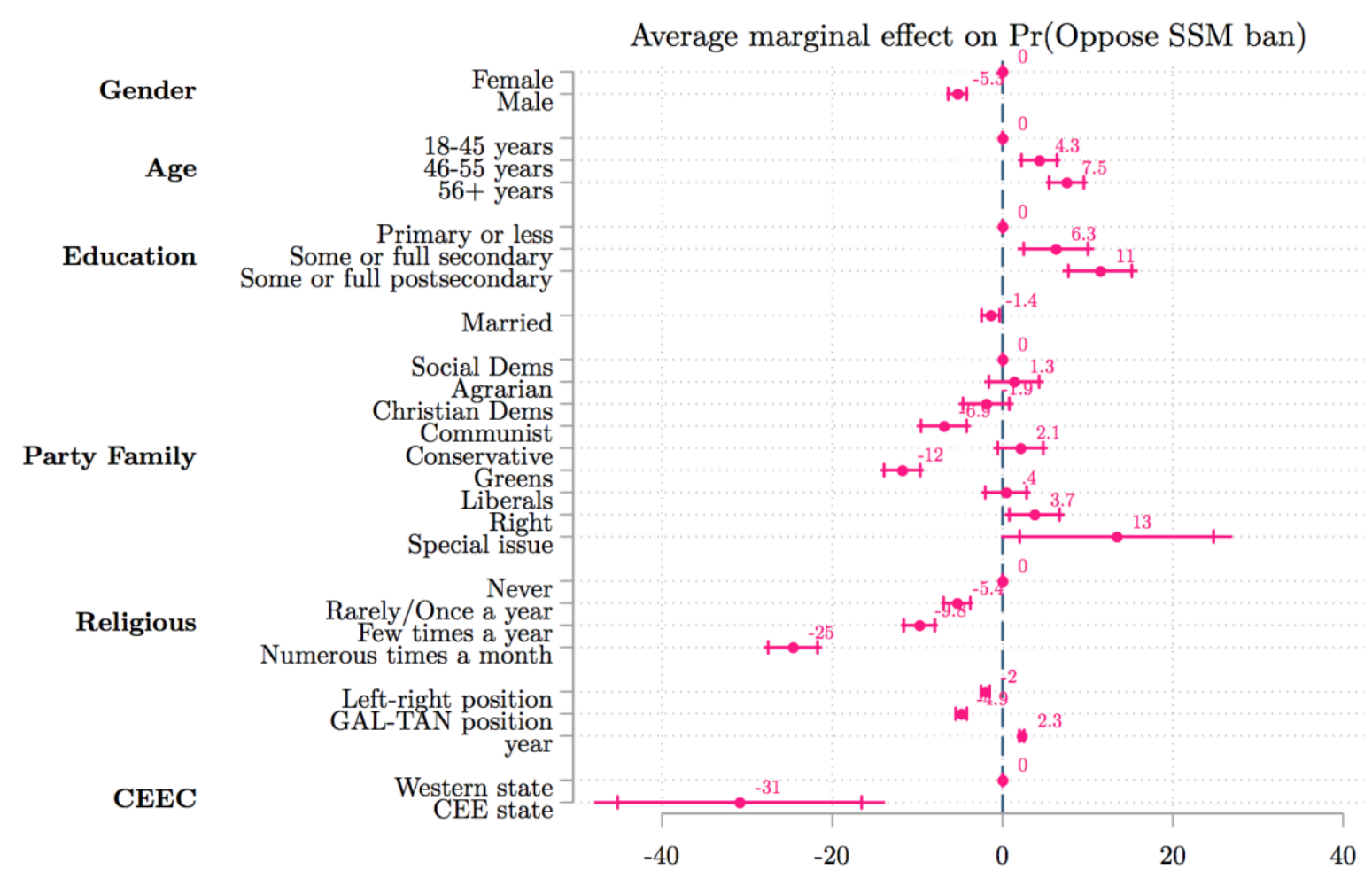

Confidence intervals at $95 \%$

Figure 1: Average marginal effects (percentage-points)

We maintain that the somewhat counterintuitive findings in the case of partisanship are partially explained by the powerful role of religiosity. As religious services attendance increases in frequency compared to those who reported never attending religious services during the year, candidates are significantly more likely to oppose equal treatment for same-sex couples. Compared to those who do not attend religious services at all, those who attend once per year are 5.4 percentage-points less likely to oppose an SSM and this gap increases to a substantive 25 percentage-point disparity when comparing the probability of opposing a ban between those who attend church on (at least) a monthly basis and those who never attend.

The distribution of candidates according religiosity is not that different across the different party families in our sample. Only about 30\% Green/ecological party 
candidates do not attend religious services at all. While higher among most other parties, with the exception of members of communist parties, that proportion is not substantially higher than candidates in other party families further to the right on cultural issues. Excluding ecological/Green parties, about 19\% of all candidates also do not attend religious services at all. In addition, about $45 \%$ of members of the ecological family of parties report attending rarely or once a year and another $20 \%$ respond a few times per year. These figures are not significantly different from candidates who belong to other party families further to the right. $26 \%$ of Conservative parties, $31 \%$ of Christian Democratic parties and even $27 \%$ of the Socialist party family attend religious services a few times per year. In the entire sample, about $12 \%$ of all respondents reported attending religious services numerous times a year, but is only $5 \%$ among members of ecological parties. But the figures are not much higher for candidates from other party families, with the exception of Christian Democratic and Conservative parties that have a higher proportion of highly religious members.

Figure 2 shows predictive margins of different levels of religious attendance conditioned by party families. The predictive margins report here come from a replication of Model 2 with the inclusion of a multiplicative interaction term between party family type and religious attendance. We see that the explanatory power of religion in determining candidates' preferences on SSM in not conditioned by their partisanship, even among parties considered part of the libertarian-left. Indeed, secular candidates from many of the major party families are more likely to oppose an SSM ban than candidates belonging ecological family of parties, the traditional supporters of postmaterialist values like LGBT equality. This includes even secular candidates from rightwing populist parties, who are likely to oppose an SSM more than any other party family with the exception of those belonging to the ecological family that attend religious services rarely or once a year are least likely to oppose an SSM ban. 
The legacy of communism in their country also substantially conditions the impact of other factors that predict support for an SSM ban. Candidates from postcommunist regimes are, on average substantially less likely (-31 percentage-points) to oppose an SSM. In our sample, of a total of $18,66 \%$ of communist members opposed a ban. The next highest are ecologists at $64 \%$ and social democrats at $46 \%$, and diminishes moving from left to right on the political spectrum, with no member of a rightwing populist party in post-communist Europe opposing such a ban.

One reason that candidates from post-communist Europe are different is higher levels of religiosity than in capitalist Europe among political candidates. While 22\% in capitalist Europe say they never attend religious services, only $7.5 \%$ report so in postcommunist Europe. Those who attend rarely or once a year is $54 \%$ in post-communist Europe, but only 38\% in capitalist Europe. At higher levels of religiosity, the figures are similar among candidates from both regions. Levels of religious observance are not higher in any particular party family, with the exception of Christian Democrats. This is similar to the pattern found among religious observers in capitalist Europe. across all levels of religiosity and party families, candidates from post-communist countries are less likely to oppose an SSM ban, with the exception of wholly secular candidates, who are slightly more likely than the most religiously observant candidates from capitalist Europe to oppose a ban. Yet, this result could also be a generated by the fact that only $9.3 \%$ of the sample contains candidates from post-communist countries. But that sample contains candidates from a diverse number of post-communist countries with different levels of opposition to a ban on SSM. The lowest level of opposition to an SSM ban is Romania (24\%), while highest in Hungary (41\%), higher than even in some countries in capitalist Europe. Finally, the differences between Cold War Eastern and Western Europe are likely driven by other confounding factors not included here found 
to affect attitudes towards homosexuality and LGBT rights, such as the candidates' countries' level of economic development, quality of democracy, or the relative impact of different transnational actors and mechanisms. Our analysis is also limited by the small number of post-communist countries in our sample.

Other socio-demographic factors also have a counter-intuitive results. Men are less likely to oppose an SSM ban than women, but not by a substantial amount (12\%). Opposition grows similarly among men and women alike, and from 53\% to 88\% among those who are married. Older candidates are more likely to oppose a ban than younger ones. Those older than 56 are 7,5 percentage-points more likely than the youngest group to oppose such a ban. These results are also likely because the sample of candidates has contains substantially more men and older candidates than found in the general population.

Finally, candidates' opinions change significantly over time to increased levels of opposition. Each year increases the chances a candidate is opposed to a ban on SSM by about 2.3 percentage-points. While the number and types of countries included in each CCS survey varies in each year, between 2006 and 2017, the percentage of candidates opposed to an SSM ban increased from 60\% to 88\%. Of all countries in which we have observations over time, only Germany and Montenegro showed no increase in opposition to an SSM ban (see Table 2), and these changes are more likely to due to sampling issues than any clear backlash to SSM. Opposition to an SSM remains around $85 \%$ in Germany, while only 38\% in Montenegro. Yet, most of the change in candidates' opinion happens mainly in Western European countries, such as in Switzerland, where opposition increases from $57 \%$ to $74 \%$, in Greece from $38 \%$ to $55 \%$, and in Portugal from 53\% to $84 \%$. 
Let us look at the distribution of attitudes towards an SSM ban across candidates with varying degrees of religiosity among the Social Democrats, one of the leading advocates of LGBTQ rights. Within the pool of Social Democratic candidates, religion plays a significant and sizeable role in establishing candidate preferences towards the prohibition of SSM. Whilst secular Social Democratic candidates have a predicted probability of opposing an SSM ban in surplus of $80 \%$, candidates from the same party family who attend church at least once monthly are more than 20 percentage-points $(\mathrm{p}<0.01)$ less likely to oppose the same ban.

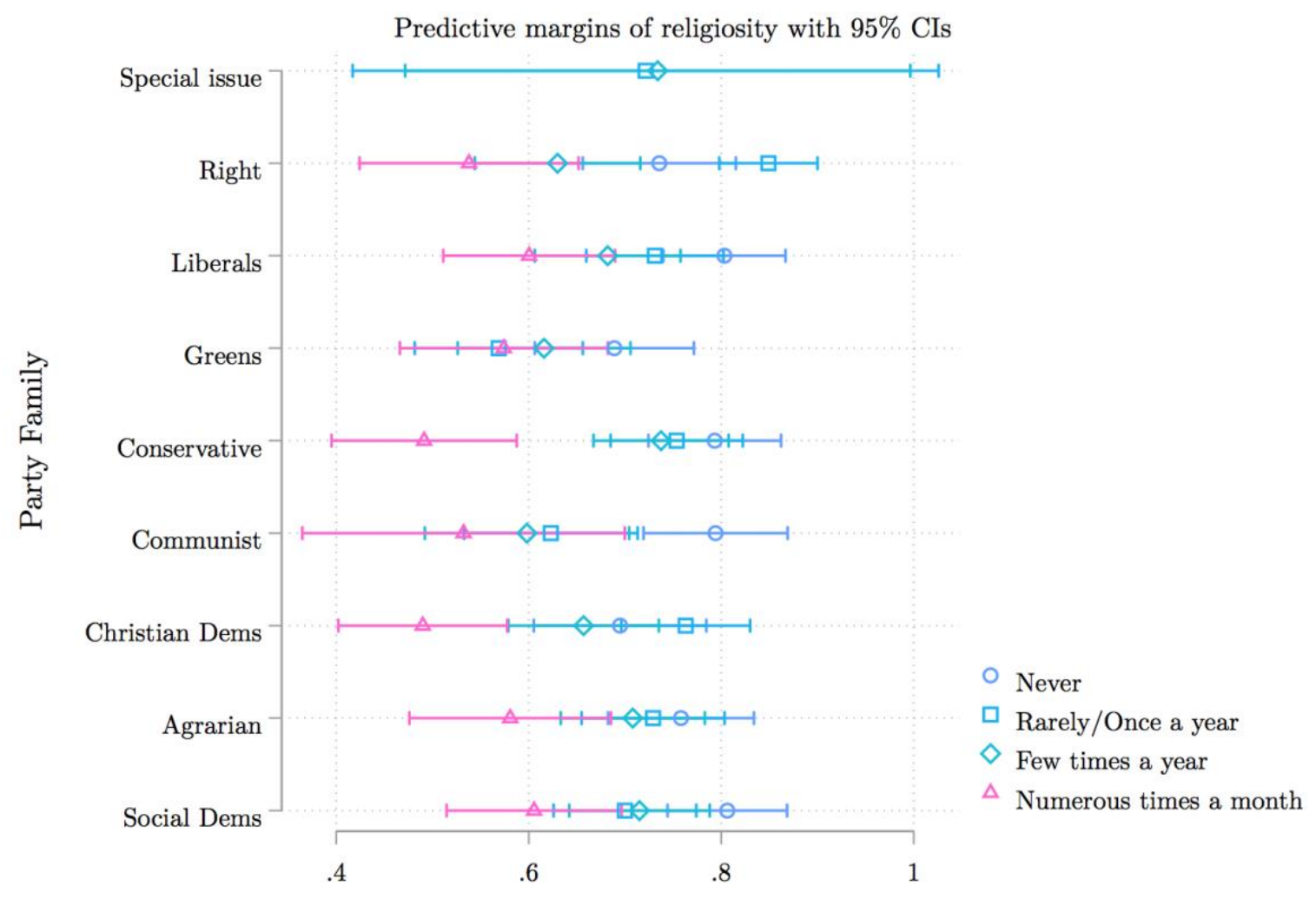

Figure 2: Religion gap conditioned by party families 
These counter-intuitive results demonstrate show that cultural values ingrained and socialized early in people's lives though religion still shape politicians' attitudes towards LGBT rights, despite the dual pressures of being required to follow the party's positions on LGBT rights, whether left or right, and changing public opinion. It is also consistent with (Arzheimer 2020) who shows that, once one considers religiosity, partisanship plays a far more diminished role in determining MPs' positions on morality issues like embryonic testing. Third, every party and party family are composed of candidates with diverse backgrounds, which include disparate levels of religiosity. We know that in two-party systems, the two parties will include members from across an ideological spectrum on some issues, producing even some intersection where social conservatives are found in traditional progressive parties and those with progressive values are found in socially conservative parties, even though the degree of overlap has decreased over time, especially in the United States. We expect less ideological overlap in multi-party systems. However, our results show this is not a safe assumption make with regard to positions candidates have on salient human rights issues, such as equal treatment for LGBTQ individuals. This is further evidence that if "free votes" are taken on LGBTQ issues, parliamentarians are not likely to follow the party line, but follow their own conscience to some degree, as shown in earlier case study research.

Therefore, why are Greens that attend church only occasionally least likely to oppose a ban on SSM? It could be partly driven by that fact that at least half of all members of this party family in our sample attend religious services rarely or once per year. There is more likely to be diversity of political opinion of SSM ban in the group than in other groups, with more people who do not support same-sex marriage. Although strong majorities of ecological party members oppose an SSM among different levels of religiosity, the highest percentage of $21 \%$ of members of ecological party members supported an SSM ban, which is higher than an average of 15\% across 
all other party families. In summary, religious observance has a significant impact on candidate's attitudes, irrespective of the party family to which they belong.

\section{Conclusion}

Among the countries that have made the most progress in advancing equal treatment for sex minorities, a substantial portion of them are parliamentary, suggesting the ideological positions of incumbent governments matters quite a bit for if and when pro-LGBT law are adopted. But focusing only on the ideological composition of the government hides a significant amount of diversity within the rank-and-file. If parties are sorted into a small set of party families, we see more heterogeneity in preferences over the passage of LGBT rights legislation than expected. Both the region of origin and levels of religious observance affect parliamentarians' attitudes towards an SSM ban. However, the party family to which a candidate belongs still matters. There are distinct differences between them with regard to support or opposition to an SSM ban. Yet, opposition to a ban on same-sex marriage increased almost universally since surveys were first conducted in the early 2000s.

One limitation of this study is that it cannot track the attitudes and voting behavior of candidates longitudinally. It is possible that these results are reflect the changing composition of party members, for example the replace of the older, socially conservative guard with younger members with more progressive values. If there is change over time within a party or among the same parties, what possible factors explain it? Are parties and candidates simply reacting to changes in public opinion? If so, are parties changing their positions on LGBT rights at the same rate as the general public across countries? Or are they reacting to other sets of pressures, such as the influence of new interest groups, transnational activists and the impact of supranational 
institutions, such as the European Union. Do political parties in multi-party systems have less incentive to change than those in systems with only a few competitive parties because the former can focus on their base voters, while larger parties are more likely to follow where general opinion goes? Did the secular trend of greater acceptance of homosexuality and equal rights for sexual minorities open up space for opponents like rightwing populists to become competitive? These are some of the questions our findings engender and still need answering.

\section{Bibliography}

Abou-Chadi, Tarik, and Ryan Finnigan. 2018. "Rights for Same-Sex Couples and Public Attitudes Toward Gays and Lesbians in Europe." Comparative Political Studies: 0010414018797947.

—. 2019. "Rights for Same-Sex Couples and Public Attitudes Toward Gays and Lesbians in Europe." Comparative Political Studies 52(6): 868-95.

Adam, Barry D. 2003. “The Defense of Marriage Act and American Exceptionalism: The 'Gay Marriage' Panic in the United States." Journal of the History of Sexuality 12(2): 259-76.

Adam, Christian, Christoph Knill, and Emma T. Budde. 2020. "How Morality Politics Determine Morality Policy Output-Partisan Effects on Morality Policy Change.” Journal of European Public Policy 27(7): 1015-33.

Adams, James, Michael Clark, Lawrence Ezrow, and Garrett Glasgow. 2004. "Understanding Change and Stability in Party Ideologies: Do Parties Respond to Public Opinion or to Past Election Results?” British Journal of Political Science 34(4): 589-610.

Arzheimer, Kai. 2015. “Strange Bedfellows: The Bundestag’s Free Vote on Pre-Implantation Genetic Diagnosis (PGD) Reveals How Germany's Restrictive Bioethics Legislation Is Shaped by a Christian Democratic/New Left Issue-Coalition." Research \& Politics 2(3): 1-7.

- 2020. "Secular Citizens, Pious MPs: Why German Attitudes about Genetic Testing Are Much More Permissive than German Laws.” Political Research Exchange 2(1): 1-25.

Asal, Victor, Udi Sommer, and Paul G. Harwood. 2013. "Original Sin: A Cross-National Study of the Legality of Homosexual Acts.” Comparative Political Studies 46(3): 320-51.

Ayoub, Phillip M. 2014. "With Arms Wide Shut: Threat Perception, Norm Reception, and Mobilized Resistance to LGBT Rights." Journal of Human Rights 13(3): 337-62. 
. 2016. When States Come Out: Europe's Sexual Minorities and the Politics of Visibility. Cambridge University Press.

Ayoub, Phillip M., and Jeremiah Garretson. 2017. "Getting the Message Out: Media Context and Global Changes in Attitudes Toward Homosexuality." Comparative Political Studies 50(8): 1055-85.

Bakker, Ryan, Seth Jolly, and Jonathan Polk. 2012. "Complexity in the European Party Space: Exploring Dimensionality with Experts.” European Union Politics 13(2): 219-45.

Banchoff, Thomas. 2011. Embryo Politics: Ethics and Policy in Atlantic Democracies Embryo Politics: Ethics and Policy in Atlantic Democracies. New York: Cornell University Press.

Benoit, K, and Michael Laver. 2006. Party Policy in Modern Democracies. Routledge. http://www.tandfebooks.com/isbn/9780203028179 (June 15, 2016).

Boertien, Diederik, and Daniele Vignoli. 2019. "Legalizing Same-Sex Marriage Matters for the Subjective Well-Being of Individuals in Same-Sex Unions.” Demography 56(6): 2109-21.

Bornschier, Simon. 2010. "The New Cultural Divide and the Two-Dimensional Political Space in Western Europe." West European Politics 33(3): 419-44.

Calvo, Kerman. 2007. "Sacrifices That Pay: Polity Membership, Political Opportunities and the Recognition of Same-Sex Marriage in Spain." South European Society and Politics 12(3): 295-314.

Caughey, Devin, T. O.M. O’Grady, and Christopher Warshaw. 2019. "Policy Ideology in European Mass Publics, 1981 2016." American Political Science Review 113(3): 674-93.

CCS. 2016. Comparative Candidates Survey Module 1 2005-2013 [Dataset - Cummulative File]. Lausanne, Switzerland: Distributed by FORS.

Chaqués, Laura, and Anna M. Roqué. 2012. "From Prohibition to Permissiveness: A Two-Wave Change on Morality Issues in Spain.” In Morality Politics in Western Europe. Parties, Agendas and Policy Choices, eds. Isabelle Engeli, Christoffer Green-Pedersen, and Lars Thorup Larsen. Basingstoke: Palgrave MacMillan, 62-87.

Cowley, Philip. 1998. "Unbridled Passions? Free Votes, Issues of Conscience and the Accountability of British Members of Parliament." Journal of Legislative Studies 4(2): 70-88.

Dejowski, E. F. 1992. "Public Endorsement of Restrictions on Three Aspects of Free Expression by Homosexuals: Socio-Demographic and Trends Analysis 1973-1988.” Journal of Homosexuality 23(4): 1-18.

Díez, Jordi. 2015. The Politics of Gay Marriage in Latin America: Argentina, Chile, and Mexico. Cambridge University Press.

Donnelly, Rachel, Brandon A. Robinson, and Debra Umberson. 2019. "Can Spouses Buffer the Impact of Discrimination on Depressive Symptoms? An Examination of Same-Sex and Different-Sex Marriages." Society and Mental Health 9(2): 192-210.

Döring, Holger, and Philip Manow. 2019. "Parliaments and Governments Database (ParlGov): Information on Parties, Elections and Cabinets in Modern Democracies."

Dotti Sani, Giulia M., and Mario Quaranta. 2020. "Let Them Be, Not Adopt: General Attitudes Towards Gays and Lesbians and Specific Attitudes Towards Adoption by Same-Sex Couples in 22 European Countries." Social Indicators Research OnlineView.

Engeli, Isabelle, Christoffer Green-Pedersen, and Lars Thorup Larsen. 2012. "Theoretical Perspectives on Morality Issues." In Morality Politics in Western Europe. Parties, Agendas and Policy Choices, eds. Isabelle Engeli, Christoffer Green-Pedersen, and Lars Thorup Larsen. Basingstoke: Palgrave MacMillan, 5-26. 
. 2013. "The Puzzle of Permissiveness: Understanding Policy Processes Concerning Morality Issues." Journal of European Public Policy 20(3): 335-52.

Fernández, Juan J., and Mark Lutter. 2013. "Supranational Cultural Norms, Domestic Value Orientations and the Diffusion of Same-Sex Union Rights in Europe, 1988-2009.” International Sociology 28(1): 102-20.

Garretson, Jeremiah J. 2018. The Path to Gay Rights: How Activism and Coming Out Changed Public Opinion. NYU Press.

Glaurdić, Josip, and Vuk Vuković. 2016. "Proxy Politics, Economic Protest, or Traditionalist Backlash: Croatia’s Referendum on the Constitutional Definition of Marriage." Europe-Asia Studies 68(5): 803-25.

Goren, Paul, and Christopher Chapp. 2017. "Moral Power: How Public Opinion on Culture War Issues Shapes Partisan Predispositions and Religious Orientations.” American Political Science Review 111(1): 110-28.

Grzymala-Busse, Anna. 2015. Nations under God: How Churches Use Moral Authority to Influence Policy. Princeton: Princeton University Press.

Hennl, Annika, and Simon Tobias Franzmann. 2017. "Organizing Political Parties: Representation, Participation, and Power." In The Effects of Manifesto Politics on Programmatic Change, eds. Susan Scarrow, Paul Webb, and Thomas Poguntke. Oxford University Press, 259-84. https://oxford.universitypressscholarship.com/view/10.1093/oso/9780198758631.001.0001/oso9780198758631-chapter-11 (September 6, 2020).

Hildebrandt, Achim. 2016. "Who's in Favour? Same-Sex Union Laws in Parliament." The Journal of Legislative Studies 22(3): 404-23.

Hooghe, Liesbet, Gary Marks, and Carole J. Wilson. 2002. "Does Left/Right Structure Party Positions on European Integration?" Comparative Political Studies 35(8): 965-89.

Inglehart, Ronald. 1997. Modernization and Postmodernization: Cultural, Economic, and Political Change in 43 Societies. Princeton University Press.

Janos, Andrew C. 2001. "From Eastern Empire to Western Hegemony: East Central Europe Under Two International Regimes." East European Politics and Societies 15(2): 221-49.

Katz, Richard S., and Peter Mair. 1993. "The Evolution of Party Organizations in Europe: The Three Faces of Party Organization.” American Review of Politics 14: 593-617.

Kitschelt, Herbert. 1994. The Transformation of European Social Democracy. Cambridge ; New York: Cambridge University Press.

Kollman, Kelly. 2007. “Same-Sex Unions: The Globalization of an Idea.” International Studies Quarterly 51(2): 329-57.

. 2013. The Same-Sex Unions Revolution in Western Democracies: International Norms and Domestic Policy Change. 1 edition. Manchester, UK: Manchester University Press.

2017. "Pioneering Marriage for Same-Sex Couples in the Netherlands." Journal of European Public Policy 24(1): 100-118.

McAllister, Ian. 1991. "Party Elites, Voters and Political Attitudes: Testing Three Explanations for Mass-Elite Differences." Canadian Journal of Political Science / Revue canadienne de science politique 24(2): 237-68.

McVeigh, Rory Mc, and Maria-Elena D. Diaz. 2009. "Voting to Ban Same-Sex Marriage: Interests, Values, and Communities." American Sociological Review 74(6): 891-915. 
Mooney, Christopher Z. 2001. "The Public Clash of Private Values.” In The Public Clash of Private Values. The Politics of Morality Policy, ed. Christopher Z. Mooney. Washington: CQ Press, 3-18.

Mucciaroni, Gary, Kathleen Ferraiolo, and Meghan E. Rubado. 2019. "Framing Morality Policy Issues: State Legislative Debates on Abortion Restrictions.” Policy Sciences 52(2): 171-89.

Norrander, Barbara, and Clyde Wilcox. 1999. "Public Opinion and Policymaking in the States: The Case of Post-Roe Abortion Policy." Policy Studies Journal 27(4): 707-22.

Norris, Pippa, and Ronald Inglehart. 2019. Cultural Backlash: Trump, Brexit, and Authoritarian Populism. New York, NY: Cambridge University Press.

O’Dwyer, Conor, and Katrina Z. S. Schwartz. 2010. "Minority Rights after EU Enlargement: A Comparison of Antigay Politics in Poland and Latvia." Comparative European Politics 8(2): 220-43.

Oppenheimer, David, Alvaro Oliveira, and Aaron Blumenthal. 2014. "Religiosity and Same-Sex Marriage in the United States and Europe.” Berkeley Journal of International Law 32(1): 195.

Plumb, Alison. 2015. "How Do MPs in Westminster-Style Parliaments Vote When Unconstrained by Party Discipline? A Comparison of Free Vote Patterns on Marriage Equality Legislation.” Parliamentary Affairs 68: 533-54.

Schattschneider, Elmer Eric. 1942. Party Government. Holt, Rinehart and Winston.

Schulenberg, Shawn. 2012. "The Construction and Enactment of Same-Sex Marriage in Argentina." Journal of Human Rights 11(1): 106-25.

Siegel, Scott N, and Yiqian Alice Wang. 2018. "Broken Rainbows: The Partisan Politics of Marriage Equality in Europe." European Politics and Society 19(4): 377-95.

Stubager, Rune. 2009. "Education-Based Group Identity and Consciousness in the Authoritarian-Libertarian Value Conflict." European Journal of Political Research 48(2): 204-33.

. 2013. "The Changing Basis of Party Competition: Education, Authoritarian-Libertarian Values and Voting." Government and Opposition 48(3): 372-97.

Štulhofer, Aleksander, and Ivan Rimac. 2009. "Determinants of Homonegativity in Europe." The Journal of Sex Research 46(1): 24-32.

Thomeer, Mieke Beth, Allen J. LeBlanc, David M. Frost, and Kayla Bowen. 2018. "Anticipatory Minority Stressors among Same-Sex Couples: A Relationship Timeline Approach.” Social Psychology Quarterly 81(2): 126-48.

Turnbull-Dugarte, Stuart J. 2020. "The European Lavender Vote: Sexuality, Ideology and Vote Choice in Western Europe." European Journal of Political Research 59(3): 517-37.

Twenge, Jean M., and Andrew B. Blake. 2020. "Increased Support for Same-Sex Marriage in the US: Disentangling Age, Period, and Cohort Effects." Journal of Homosexuality: 1-11.

Velasco, Kristopher. 2020. "Queering the World Society: Global Norms, Rival Transnational Networks, and the Contested Case of LGBT Rights.” SocArXiv. https://osf.io/preprints/socarxiv/3rtje/ (August 29, 2020).

Wagner, Markus. 2020. “Affective Polarization in Multiparty Systems.” Electoral Studies: 102199. 
Appendix Table A. Descriptive Statistics

\begin{tabular}{|c|c|c|c|}
\hline \multicolumn{4}{|l|}{ Variable } \\
\hline \multicolumn{4}{|l|}{ Left/Right } \\
\hline \multicolumn{4}{|c|}{ Mean $=4.9 ;$ Min. $=.5 ; \operatorname{Max}=9.66$} \\
\hline \multicolumn{4}{|l|}{ Liberty/authority9 } \\
\hline \multicolumn{4}{|c|}{ Mean $=4.41 ;$ Min. $=1.01 ; \operatorname{Max}=9.79$} \\
\hline & $N$ & Sample Share (\%) & Oppose Ban (\%) \\
\hline \multicolumn{4}{|l|}{ Gender } \\
\hline Female & 9,505 & 36 & 86.6 \\
\hline Male & 17,032 & 64 & 79.8 \\
\hline \multicolumn{4}{|l|}{ Age Group (years) } \\
\hline $18-45$ & 1,999 & 7.2 & 72.8 \\
\hline $46-55$ & 4,899 & 17.8 & 78.8 \\
\hline 56 and over & 20,656 & 75.0 & 84.0 \\
\hline \multicolumn{4}{|l|}{ Education } \\
\hline Primary or Less & 582 & 2 & 81.6 \\
\hline Some or full secondary & 3,648 & 13 & 78.2 \\
\hline Complete secondary & 23,646 & 85 & 83.0 \\
\hline \multicolumn{4}{|l|}{ Religious Attendance } \\
\hline Never/Rarely/Once a Year & 3,584 & 12.9 & 87.7 \\
\hline Few Times a Year & 7,416 & 25.6 & 81.9 \\
\hline Numerous Times & 16,876 & 60.5 & 57.9 \\
\hline \multicolumn{4}{|l|}{ Party Family } \\
\hline Agrarian & 1,752 & 7.19 & 76.8 \\
\hline Christian Democracy & 3,521 & 14.4 & 63.1 \\
\hline Communist/Socialist & 1,800 & 7.38 & 90.9 \\
\hline Conservative & 2,743 & 11.3 & 77.4 \\
\hline Green/Ecologist & 4,100 & 16.8 & 90.4 \\
\hline Liberal & 3,565 & 14.6 & 86.9 \\
\hline Right-wing & 1,559 & 6.4 & 68.1 \\
\hline Social Democracy & 5,041 & 20.7 & 90.8 \\
\hline Special Issue & 290 & 1.2 & 93.8 \\
\hline t.b.d. & 11 & 0.05 & 82.5 \\
\hline \multicolumn{4}{|l|}{ Married } \\
\hline Married & 15,383 & 55 & 80.4 \\
\hline Other & 12,493 & 45 & 84.7 \\
\hline \multicolumn{4}{|l|}{ Region } \\
\hline Capitalist & 2,597 & 9.32 & 83.5 \\
\hline Former Communist & 25,279 & 90.7 & 70.8 \\
\hline
\end{tabular}

9 (Benoit and Laver 2006) 